\title{
N-benzylidene-2-aminobenzimidazol as a New Corrosion Inhibitor for Mild Steel in $\mathrm{HCl}$
}

\section{B. ABDULWAHHAB TAHER AL-MAYYAHI, M. KAMAL. JOUDAH, A. ABDULRAZZAQ. ABDULWAHID, H. T. ABDULSAHIB and A.Y. ISSA RUBAYE*}

\author{
Chemistry Department, College of Science, Basrah University, Basrah- Iraq. \\ ${ }^{*}$ Corresponding author E-mail: issaay86@yahoo.co.uk
}

http://dx.doi.org/10.13005/ojc/330544

(Received: Feb 04, 2017; Accepted: May 05, 2017)

\begin{abstract}
$\mathrm{N}$-benzylidene-2-aminobenzimidazol (BA) has been investigated as corrosion inhibitor for mild steel in corrosive solution utilizing weight loss technique complemented with Scanning electron microscopy (SEM).The weight loss method results clarified that BA has good inhibiting impact for mild steel corrosion in corrosive solution, with efficiency of $79 \%$ at a highest utilizing concentration. BA was synthesized by the reaction of benzaldehyde with 2-aminobenzimidazol. Metal-complex that formed between metal and $\mathrm{N}$ benzylidene-2-aminobenzimidazol (BA) has been postulated inhibition mechanism of mild steel corrosion. Quantum chemical calculations agree with experimental results.
\end{abstract}

Keywords: N-benzylidene-2-aminobenzimidazol (BA), Corrosion Inhibition, weight loss method, Scanning Electron Microscopy (SEM), Quantum chemical calculations .

\section{INTRODUCTION}

Anti-corrosive compounds have considerable agreement in industry due to superior inhibiting characteristics. However, numerous displayed as one of the major impact, damage the environment, therefore the scientific community start for examination of eco-friendly corrosion inhibitors, comparable to the organic inhibitors ${ }^{1-4}$. A significant number of research articles were published with the objective of improve an eco-friendly corrosion inhibitors and many investigations were act to improving green-inhibitors ${ }^{5}$. Moreover, increasing of published articles in natural products, like plant extract and essential to acquire eco-friendly corrosion inhibitors ${ }^{7}$.Chemical inhibitors have been predominating utilized for such procedure, mostly to monitoring the metal degeneration and acid exhaustion. The puberty of the most utilized corrosion inhibitors were chemical organic molecules that have nitrogen, sulfur and/or oxygen atoms ${ }^{8,9}$. The planarity and electrons pairs that located in $\mathrm{N}, \mathrm{O}$ and $\mathrm{S}$ atoms were the significant structural characteristics that monitoring the 
adsorption of such molecules onto the mild steel surface. The significance of this research has in confirm the previously certain results on the corrosion inhibition impact of diverse Schiff bases on mild steel in corrosive bath ${ }^{10-30}$. In this paper we report the synthesis of, N-benzylidene-2-aminobenzimidazol (BA). Structure for BA has been established, utilizing elemental and spectroscopically techniques. The inhibition impact on BA of MS in $1.0 \mathrm{M}$ corrosive bath have been investigated utilizing weight loss method.

\section{EXPERIMENTAL METHODS}

\section{Inhibitors Synthesis}

BA has been synthesizing successfully as displayed in Scheme 1. The required chemicals for BA preparation had been covered from Sigma Aldrich. The infrared spectra were recorded on a shimadzu FT-IR-8300 spectrometer. nuclear magnetic resonance (NMR) spectra were recorded on Bruker Spector-spin ultra-shield magnets 300 $\mathrm{MHz}$ instrument utilizing TMS and DMSO-d6. Schiff base was prepare according to the method reported in references ${ }^{31-52} \mathrm{~A}$ solution of 2-aminobenzimidazol $(0.3 \mathrm{mmol})$ in $70 \mathrm{ml}$ of ethyl alcohol have been refluxed with benzaldehyde $(0.3 \mathrm{mmol})$ for 4 hours. Left the solution to cool at room temperature, a solid mass separated from solution and was recrystallized from ethanol to afford the target compound in $87 \%$ yield. FT-IR in cm-1: 3297.3 for $\mathrm{N}-\mathrm{H}, 3066.1$ for $\mathrm{C}-\mathrm{H}$ aromatic, 1623.8 for $\mathrm{C}=\mathrm{N}, 1569.2$ for $\mathrm{C}=\mathrm{C}$ aromatic and others $(1445.6,1269.6,801,7,701.7) \mathrm{cm}^{-1} .1 \mathrm{H}$ NMR: 10.95 for $\mathrm{N}-\mathrm{H}(\mathrm{s}, 1 \mathrm{H}), 8.47$ for $\mathrm{C}-\mathrm{H}(\mathrm{s}, 1 \mathrm{H})$ and 7.02-7.95 for benzene rings $(\mathrm{m}, 9 \mathrm{H}) \mathrm{ppm} .13 \mathrm{C}-$ NMR: $160.4,156.6,136.1,135.2,134.7$, , 130.1, 129.4, 124.5, 113.5 and $113.1 \mathrm{ppm}$. Elemental Analysis: C, 76.00(76.69); H, 5.01(5.36); N, 18.99(19.24).

\section{Weight Loss Method}

MS specimen has been covered from Metal/Company/Samples and has been used as an electrode in this investigation. Percentage weight composition of the MS specimen as alloy was: [99.21 iron]; [0.21 carbon]; [0.38 silicon]; [0.09 phosphorous], [0.05 manganese]; [0.05 Aluminum]. Regarding to the standard technique (G1-03) that was published in ASTM, the mild steel surface had been cleaned. First step was to suspended in duplicate the specimens with $200 \mathrm{ml}$., solutions with/without various conc. of $\mathrm{BA}$ as an inhibitor $(0.0,0.05,0.1,0.15,0.2,0.25$ and $0.5 \mathrm{mM})$. After immersion times $1 \mathrm{~h}, 2 \mathrm{~h}, 3 \mathrm{~h}, 4 \mathrm{~h}, 5 \mathrm{~h}, 10 \mathrm{~h}, 24$ $h$. The specimen was washed, dried and weighed accurately. Inhibition efficiency IE (\%) was determined according to Equation 1;

$I E \%=\left(1-\frac{w_{2}}{w_{1}}\right) \times 100$

\section{Quantum chemical calculation}

Quantum chemical calculations with molecular simulations have been done through density functional theory (DFT) method at the B3LYP and O3LYP/6-31+G(d,p) basis set level. The molecular structure of the inhibitor was fully geometrically optimized.

\section{RESULTS AND DISCUSSION}

The synthesis of BA ( $\mathrm{N}$-benzylidene-2aminobenzimidazol), was done by refluxing of a reaction mixture of 2-aminobenzimidazol with benzaldehyde. Reaction sequence for the formation the BA inhibitor that derived from benzimidazol is outline in Scheme 1.

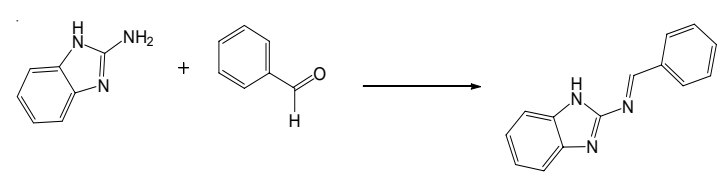

Scheme. 1. Reaction synthesis of BA.

\section{Concentration Impact}

The impact of increment of BA in acid bath on the corrosion of mild steel was investigated regarding to weight loss technique for a period of time $(1,2,3,4,5,10$ and $24 \mathrm{~h})$ at $303 \mathrm{~K}$. The impacts of corrosion rates and inhibition efficiency with $(0.0$, $0.05,0.1,0.15,0.2,0.25$ and $0.5 \mathrm{mM}$ ). of BA were shown in Fig. 1 and Fig. 2. The the inhibition efficiency IE (\%)were evaluated regarded to Equation 1 and corrosion rate were evaluated regarded to Equation 2:

$$
C_{R}=\frac{87.6 w}{a t \rho}
$$

Where, $w$ is the weight loss, $\tilde{n}$ is the density of mild steel, $a$ is the area of specimen and $t$ is the time of immersion. 


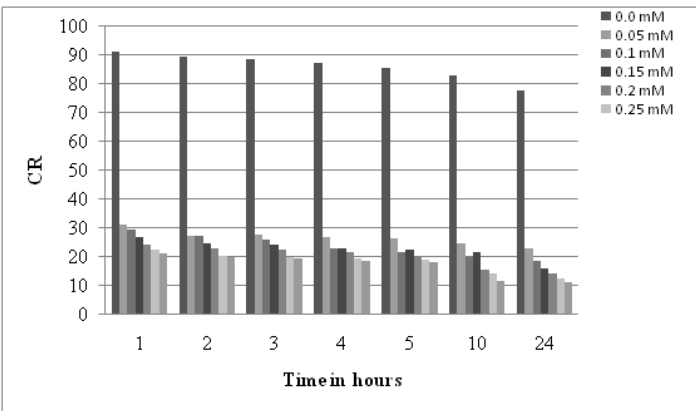

Fig. 1. Impactof concentration of BA on corrosion rate at various times

The corrosion rate significantly diminish and the inhibition efficiency would improve with the raising of concentration of $\mathrm{BA}$. The enhancement of inhibition efficiency with the raising concentration was due to the raise in the range of protection efficiencies of BA.

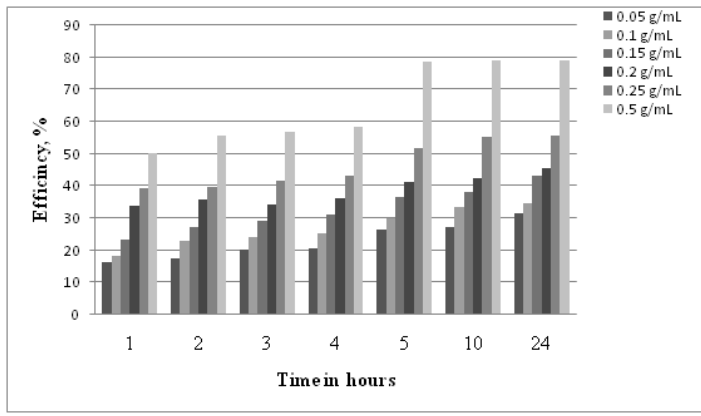

Fig. 2. Impact of concentration of BA with various times at $303 \mathrm{~K}$

\section{Temperature Impact}

The inhibition efficiencies of BA on mild steel in acidic bath with various concentrations $(0.0$, $0.05,0.1,0.15,0.20,0.25$ and $0.50 \mathrm{mM})$ of BA at temperatures $(303,313,323$ and $333 \mathrm{~K}$ ) showed that IE enhanced with the highest concentration of BA. Moreover it decreased with raising of temperature of solution as displayed in Fig. 3. For the processof adsorption of BA molecules, the heat of adsorption is significantly negative, that will lead to one truth this is an exothermic process. This is the would be the reason that the efficiencies would diminish in the case of rising of temperature.

\section{Scanning electron microscopy (SEM)}

According to Fig. 4 and 5 , it can be shown that the mild steel surface was significant attacked by hydrochloric acid and become harsh but $\mathrm{N}$ - benzylidene-2-aminobenzimidazol has the ability to completely protective potentiality the mild steel surface an keep it smooth as in Figure. 5.

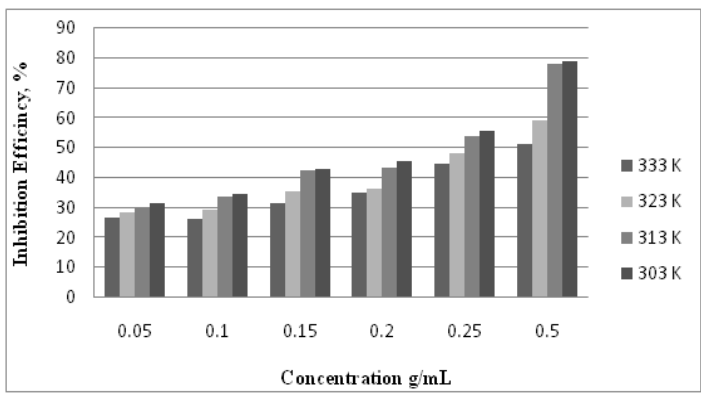

Fig. 3. Rising temperatures impact of on efficiencies of BA at various concentrations

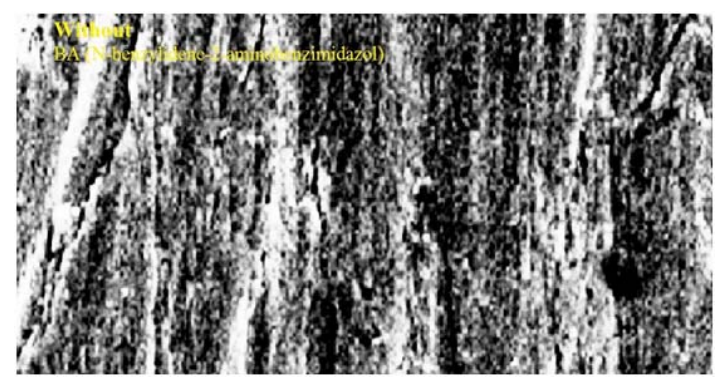

Fig. 4. The SEM micrograph for mild steel in $1.0 \mathrm{M}$ $\mathrm{HCl}$ at $30^{\circ} \mathrm{C}$ for $5 \mathrm{~h}$ as immersion time

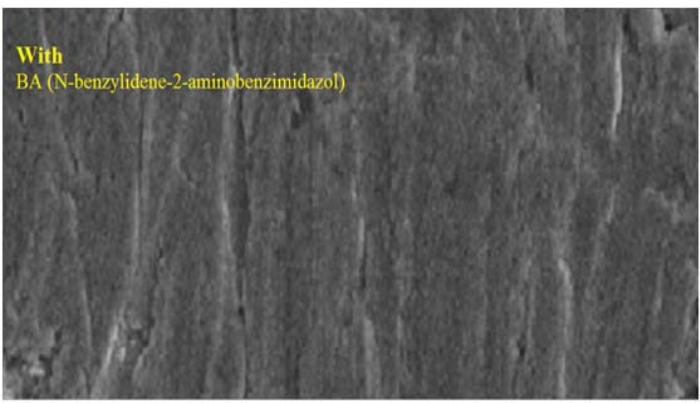

Fig. 5. The SEM micrograph for mild steel in $1.0 \mathrm{M}$ $\mathrm{HCl}$ with $0.5 \mathrm{mM}$ of coumarin-3-amine at $30^{\circ} \mathrm{C}$ for 5 $h$ as immersion time

\section{Quantum chemical calculation}

To understanding the mechanism of interaction for $\mathrm{N}$-benzylidene-2-aminobenzimidazol as inhibitor molecules and mild steel surface, the quantum chemical calculations had been done. The optimizing structure for N-benzylidene-2-aminobenzimidazol was demonstrated in Figures. 6. 


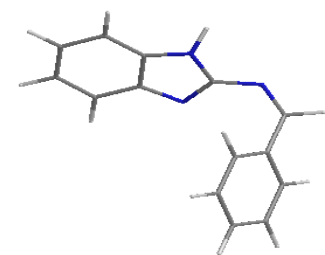

Fig. 6. The optimized structure of $\mathrm{N}$-benzylidene-2aminobenzimidazol

Figure. 7 displayed the highest occupied molecular orbital (HOMO) and lowest unoccupied molecular orbital (LUMO), respectively. According to the molecular orbital theory, the transition state formed because of the interaction between highest occupied molecular orbital that has the abilities to donate electrons and lowest unoccupied molecular orbital that has the abilities to accept electrons of $\mathrm{N}$-benzylidene-2-aminobenzimidazol.

It can be shown from Fig that the highest occupied molecular orbital has been distribute over aminobenzimidazol but not the benzene ring because of electron pair of nitrogen atom that delocalized with aminobenzimidazol ring, that indicates that prefers an electrophilic attacks. The LUMO has been locate just on the benzylidene, that reveal that activities toward nucleophilic attacks.

From this result it could be suggest that isomethan group in N-benzylidene-2aminobenzimidazol has been react with surface of the mild steel as shown in Figure. 8.

\section{CONCLUSIONS}

BA (N-benzylidene-2-aminobenzimidazol) was successfully synthesized and identified by spectroscopic methods named; NMR, FT-IR and by elemental analysis. The studied outcomes implied

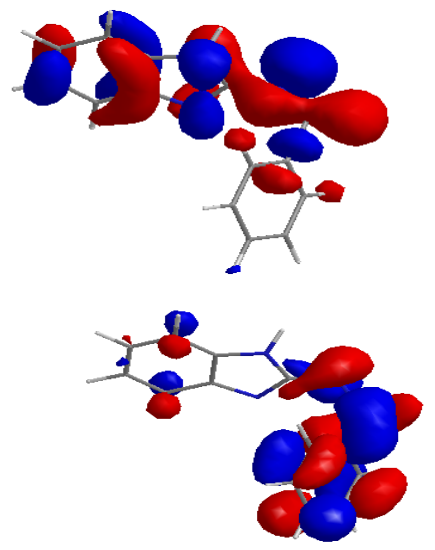

Fig. 7. The HOMO and LUMO structures for the $\mathrm{N}$-benzylidene-2-aminobenzimidazol.

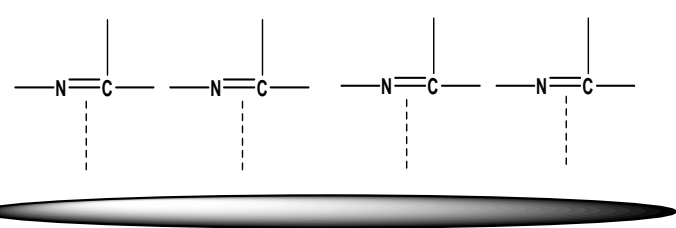

Fig. 8. The Mechanism of inhibition based of DFT.

that BA (N-benzylidene-2-aminobenzimidazol) was a good corrosion inhibitor for in acidic bath for mild at various concentrations. Inhibition efficiencies of $\mathrm{BA}$ ( $\mathrm{N}$-benzylidene-2-aminobenzimidazol) at the maximum concentration was $78.9 \%$ and diminish with a rising temperature degrees. BA ( $N$ benzylidene-2-aminobenzimidazol) was showing these perfect efficiencies due to its structure that has three nitrogen atoms.

\section{ACKNOWLEDGEMENT}

The authors are thankful to the government of Iraq, , Ministry of Higher Education and Basrah University for the financial support provided for this work.

\section{REFERENCES}

1. Abdel-Gaber, A.M. ; Abd-El-Nabey, B.A. ; Khamis, E.; Abd-El-Khalek, D.E.Desalination. 2011, 278 (1-3), 337-342.

2. Blustein, G. ; Romagnoli, R.; Jean, J.A. Colloids and Surfaces A: Physicochemical and Engineering Aspects. 2006, 290 (1-3), 7-18.
3. Bommersbach, P.; Alemany-Dumont, C.; Millet, J.P.; Normand, B. Electrochimica Acta. 2005, 51(6), 1076- 1084.

4. Lecante, A.; Robert, F.; Blandinières , P.A.; Roos , C. Current Applied Physics. 2011, 11(3), 714-724. 
5. El Bribri, A.;Tabyaoui , M.; Tabyaoui, B.; E Attari , H.; Bentiss , F. Materials Chemistry and Physics. 2013, 141(1), 240-247.

6. Znini , M.; Majidi , L.; Bouyanzer, A.; Paolini ; Desjobert, J; Costa, J. ; Hammouti , B. Arabian Journal of Chemistry. 2012, 5( 4), 467-474.

7. Amitha Rani , B. E. ; Bharathi, J. B. An Overview. International Journal of Corrosion. 2012, 2012, 1- 15.

8. Laamari, M.R.; Benzakour, J.; Berrekhis, F.; Bakasse, M.; Villemin, D. J. Mater. Environ. Sci. 2012, 3, 485-496.

9. Wang, L. Corros. Sci. 2001, 43, 1637-1644.

10. Sekine, I.; Nakahata, Y.; Tanabe, H. Corros. Sci. 1988, 28, 987-1001.

11. Al-Amiery, A. A. ; Al-Majedy, Y. K. ; Kadhum, A. A. ; Mohamad, A. B. Molecules. 2015 , 20(1), 366-383.

12. Muralidharan, S. ; Quraishi, M.A. ; Iyer, S.V.K. Corros. Sci. 1995, 37, 1739.

13. Elewady, G.Y. J. Electrochem. Sci. 2008, 3, $1149-1161$.

14. Al-Amiery, A. A. ; Kadhum, A. A. H.; Mohamad, A.B.; Musa, A.Y.; Cheong, J. L. Materials. 2013, 6(12), 5466-5477.

15. Maqsood, A. M. ; Mohd, A. H. ; Firdosa, N.; Shaeel, A. A. ; Moretti, G.; Quartarone, G.; Tassan, A. ;Zingales, A. Electrochem. Acta. 1996, 41, 1971.

16. Cannito, A.; Pemmsin, M.; Lnu-Due, C.; Hoguet, F.; Gaultier, C . ; Narcisse, J. Eur. J. Chem. 1990, 25, 635.

17. Chakaravorty, P. K.; Grelnlee, W. J.; Dooseap, K. ; Mantlo, N. B. ; Patchett, A. A. Int. Appl. WO Chem. Abstr. 1992,92 (20), 687.

18. Al-Azawi, F.; Al-Baghdadi, S.; Mohamed, A. ; Al-Amiery, A. ; Abed, T. ; Mohammed, S.; Kadhum, A. A. H. ; Mohamad, A. B. Chemistry Central Journal. 2016, 10 (1), 1-9.

19. Junaedi, S.; Kadhum, A.A.H.; Al-Amiery, A.A.; Mohamad, A.; Takriff, M. Int. J. Electrochem. Sci. 2012, 7, 3543-3554.

20. Al-Amiery, A.; Kadhum, A.; Alobaidy, A.; Mohamad, A.; Hoon, P. Materials. 2014, 7, 662-672.

21. Lopez-Sesenes, R.; Gonzalez-Rodriguez, J. G.; Casales, M.; Martinez, L.; SanchezGhenno, J. C. Int. J. Electrochem. Sci. 2011, 6, 1772-1784
22. Al-Amiery, A.; Kadhum, A.; Mohamad, A.; Musa , A.; Li , C. Materials. 2013, 6, 5447-5466.

23. Al-Amiery, A.; Al-Majedy, Y.K.; Kadhum, A.H.; Mohamad, A. Molecules. 2015, 20, 366-383.

24. Bilgic, S.; Alýskan, N. C. J. Appl. Electrochem. 2001, 31, 79-83.

25. Alobaidy, A.; Kadhum, A.; Al-Baghdadi, S.B.; Al-Amiery, A.; Kadhum, A.H.; Yousif, E. Int. J. Electrochem. Sci. 2015, 10, 3961-3972.

26. Li, W.; He Q.; Zhang, S.; Pei, C.; Hou, B. J. Appl. Electrochem. 2008, 38, 289.

27. Al-Amiery, A.; Kassim, F.A.; Kadhum, A.H.; Mohamad, A. Sci. Rep. 2016, 6, 1-13.

28. Barthakur, M. G. ; Borthakur, M. ; Devi, P. ; Saikia, C. J. ; Saikia, A. ; Bora, U. ; Chetia, A.; Boruah, R. C. Synlett. 2007, 223-226.

29. Bentiss, F.; Traisnel, M.; Vezin, H.; Hildebrand, H. F.; Lagrenee, M. Corros. Sci. 2004, 46, 2781.

30. Al-Amiery, A.; Kadhum, A.; Mohamad, A.; Junaedi, S. Materials. 2013, 6, 1420-1431.

31. Abdulghani, A.J.; Hussain, R.K. Open Journal of Inorganic Chemistry. 2015, 5, 83101.

32. Al-Majedy, Y.; Al-Amiery, A.; Kadhum, A. BioMed Research International. 2016, 2016, 1-7.

33. Bukhari, I.H.; Arif, M.;Akbar, J. ; Khan, A.H. Pakistan Journal of Biological Sciences. 2005, 8, 614-617.

34. Anacona, J.R.; Calvo, J.; Almanza, O.A. International Journal of Inorganic Chemistry. 2013, 2013, 1 - 7.

35. Al-Majedy, Y.; Kadhum, K.; Al-Amiery, A.A.H. Molecules. 2014, 19(8),11791-9.

36. Al-Majedy, Y.K.; Al-Amiery, A.A.; Kadhum, A.A.H.; Mohamad, A.B. PLoS ONE. 2016, 11(5), 1-13.

37. Al-Noor, T.H.; Al-Jeboori, A.T.; Aziz, M.R. Advances in Physics Theories and Applications. 2013, 18, 1-8.

38. Al-Majedy, Y.K.; Al-Duhaidahawi, D.; Al-Azawi, K.; Al-Amiery, A.A.; Kadhum, A.A.H.; Mohamad, A.B. Molecules. 2016, 21, 135-45.

39. Kadhum A.; Al-Amiery, A.; Musa, A.; Mohamad, A. Int. J. Mol. Sci. 2011,12(9),5747-5761.

40. Kadhum, A.; Mohamad, A.; Al-Amiery, A.; Takriff, M.S. Molecules. 2011, 16,6969-6984.

41. Naz, N.; Iqbal, M.Z. Science International (Lahore). 2011, 23, 27-31.

42. Al-Amiery, A.A.; Musa, A.Y.; Kadhum, A.; Mohamad, A. Molecules. 2011, 16(8), 6833-6843. 
43. Bhrigu, B.; Pathak, D.; Siddiqui, N.;Alam, M.S; Ashen, W. A Short Review. International Journal of Pharmaceutical Science and Drug Research (IJPSDR). 2010, i, 229-235.

44. Al-Majedy Y.K.; Kadhum, A. ; Al-Amiery, A. ; Mohamad , A. Sys Rev Pharm. 2017,8(1),1-7.

45. Pal, M.; Sharma, N.K.; Jha, P.K.K. A Review. Journal of Advanced Scientific Research. 2011, 2, 35-44.

46. Al-Amiery, A.; Al-Majedy, Y.; Kadhum, A. PLoS ONE. 2015, 10 (7), 1- 9.

47. Verma, M.; Pandeya, S.N.; Singh, K.N. ; Stables, J.P. Acta Pharmaceutica. 2004, 54, 49-56.
48. Al-Amiery, A.A.; Al-Bayati, R.; Saour, K.; Radi, M. Research on Chemical Intermediates. 2012, 38(2), 559-69.

49. Nigam, P.; Mohan, S.W.; Kundu, S.; Prakash, R. Talanta. 2009, 77, 1426-1431.

50. Al-Amiery, A.A.; Al-Majedy, Y.K. ; Kadhum, A.A.H.; Mohamad, A. Sci Rep. 2015, 5,11825

51. Kshash, A.H. Journal of Anbar Veterinary Science. 2010, 3, 125-132.

52. Al-Amiery, A.A.; Al-Majedy, Y.K.; AlDuhaidahawi, D.; Kadhum, A.A.H.; Mohamad, A.B. Free Radicals and Antioxidants. 2016, 6(2), 173-7 